\title{
Model Tes Bakat Calon Atlet Sepakbola Untuk KU 9-10 Tahun
}

\author{
${ }^{1}$ Endarman Saputra, S.Pd., M.Pd \\ ${ }^{2}$ Reza Hadinata, S.Si., M.Pd \\ Correspondence: Fakultas Ilmu Keolahragaan, Universitas Jambi, Jambi, \\ Indonesia. \\ E-mail: endarman@unja.ac.id, rezahadinata@gmail.com
}

\begin{abstract}
This research aims to develop a model of basic skill test for talent scouting soccer athlete candidates of age group of 10-11 years which is valid and reliable. This research is research and development adapting research measures proposed by Borg and Gall (2007: 590) including: (1) introductory study and data collection, (2) planning and conducting research, (3) product validation, (4) trying out of the product, (5) revisions of the product, and (6) product implementation. The try out of the initial product was conducted to 30 students. The try out of the main product was conducted to 416 students from various elementary schools (SD) sampled using the cluster sampling technique. The data validity is calculated using with Pearson's Product Moment correlation and the reliability was calculated using the test-retest of Cronbach's Alpha. The $Z$ score was used to equalize the form of units. The results of this research and development include a model of basic skill test for talent scouting soccer athlete candidates of age group of9-10 years. The talent test model is fit for use, because it is valid and reliable, with the raccount score

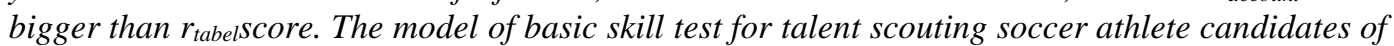
age group of 9-10 years includes the assessment scales (norms) that are packed in the effective and efficient guidebook (module) and visualization/tutorial tests (CD) that can be used as a manual of the soccer academy coaches in the process of scouting prospective athletes with different levels of talent.
\end{abstract}

\section{Keywords: Soccer Talent Test Model}

\section{Pendahuluan}

Proses pembinaan olahraga merupakan suatu prosedur yang harus dilaksanakan untuk mencapai sebuah prestasi. Dalam upaya dan usaha tersebut tentu banyak hal yang harus dipertimbangkan, agar setiap tahap dalam proses pembinaan berjalan dengan baik dan benar. Banyak faktor yang mempengaruhi keberhasilan dari sebuah proses pembinaan olahraga. Hasil pembinaan olahraga berupa prestasi terbaik tidak diperoleh dengan mudah.Banyak tantangan dan rintangan yang harus dihadapi.Setiap pelaku olahraga harus mampu untuk bekerjasama secara berkesinambungan. Agar nantinya jika kelak permasalahan yang terjadi dalam proses pembinaan olahraga dapat diselesaikan dengan bijaksana, dimulai dari manajemen kepengurusan olahraga hingga pola pembinaan atlet.

Hal tersebut bisa diwujudkan dengan membentuk suatu mekanisme kepengurusan yang solid, karena secara gamblang hal tersebut akan memberikan efek yang positif pula terhadap perkembangan atlet. Karena pada proses awal pembinaan atlet, program masih difokuskan untuk menelaah calon atlet secara

PJKR_

http://jurnal.unimed.ac.id/2012/index.php/jpehr/index 
umum, dengan melihat berbagai faktor tertentu. Jika calon atlet memiliki kemampuan gerak dan keterampilan pokok yang mumpuni, tentu calon atlet tersebut masih memiliki peluang besar untuk memilih dan menentukan cabang olahraga yang diminatinya, mengingat berbagai potensi yang dimiliki calon atlet tersebut yang terbilang cukup komplit.Hal tersebut masih dapat ditoleransi, mengingat pada tahap usia dini merupakan masa dilakukannya berbagai pendekatan terhadap calon atlet mengenai pandangan tentang berbagai keputusan yang harus ditentukan. Pendekatan tersebut harus dilakukan secara berkesinambungan oleh pihak terdekat calon atlet, baik orang tua maupun keluarga.Oleh karena itu, pola pembinaan atlet yang tepat dan sesuai dengan cabang olahraga merupakan landasan utama pencapaian sebuah prestasi maksimal.

Secara khusus pembinaan merupakan salah satu proses yang harus dilaksanakan untuk mencapai suatu prestasi. Karena dalam mencapai suatu prestasi, banyak faktor yang mempengaruhi. Dalam ranah keolahragaan, sebuah proses pembinaan harus dibangun secara bertahap, dimulai dari pembinaan usia dini hingga pembinaan pada tingkat atlet profesional. Dalam merancang sebuah program pembinaan yang efektif dan efisien, kemungkinan besar akan menghasilkan atlet yang memiliki kemampuan yang sangat luar biasa. Hal tersebut bisa dilakukan dengan mempersiapkan pelayanan (treatment) yang profesional dalam proses pembinaan yang dilakukan oleh para pelatih, guru, maupun tenaga kependidikan jasmani lainnya yang tentu akan meningkatkan kualitas dari pembinaan formal maupun informal pada tahap usia dini tersebut (Martinek \& Hellison, 2009, p.15).

Jika menilik pada proses pembinaan usia dini, tentu tak akan lepas dari topik tentang penelusuran bakat. Penelusuran bakat merupakan tahap awal yang harus dilakukan sedini mungkin sesuai dengan karakteristik cabang olahraga tertentu. Menurut Beswick (2010, p.8) secara khusus, di dalam sebuah proses pembinaan, identifikasi bakat (talent) merupakan tahap awal yang perlu dilaksanakan sejak usia dini (grass root). Pada prosesnya, calon atlet yang dinyatakan berbakat, akan mengemban tanggung jawab pribadi (commitment). Rasa tanggung jawab diperoleh dari pemahaman yang diberikan oleh orang tua. Setelah calon atlet memiliki rasa tanggung jawab yang baik, peran program latihan (coachability) yang dijalankan oleh pelatih juga memberikan peran yang cukup signifikan dalam proses menjaga dan membentuk atlet yang hebat. Pada akhirnya, ketika semua tahapan telah dijalani dengan baik, hanya atlet yang memiliki mental yang tangguh (mental toughness) yang akan mencapai kesuksesan (success) baik berupa persaingan antar-pemain maupun bangkit pascacidera. Setiap cabang olahraga tentu memiliki karakteristik program pembinaan yang berbeda-beda. Begitu juga dengan sepakbola, yang memiliki kriteria kategori kelompok usia pembinaan tertentu.

PJKR_

http://jurnal.unimed.ac.id/2012/index.php/jpehr/index 


\section{Pustaka}

Menurut Wein (Stratton, et. al, 2004, pp.163-164) pada hakikatnya, terdapat beberapa pengkategorian program pembinaan dalam sepakbola yang diterima oleh anak usia dini secara umum, yakni: usia 7-8 tahun dimana tahap perkenalan sepakbola dilakukan, usia 8-10 tahun dimana pengembangan keterampilan dasar sepakbola mulai dilakukan, 10-12 tahun dimana permainan sepakbola sederhana dalam bentuk mini mulai dilakukan, 12-15 tahun dimana pola permainan sepakbola mulai diperkenalkan dalam bentuk yang sederhana, dan usia 15 tahun keatas dimana taktik dan strategi baik secara individu maupun tim mulai diperkenalkan dalam bentuk yang lebih sederhana.

Bakat merupakan faktor bawaan yang dimiliki oleh setiap manusia, baik secara fisik maupun mental.Menurut Renzulli (Sternberg \& Davidson, 2005, pp.256-257) bakat memiliki beberapa karakteristik tertentu, diantaranya kemampuan di atas rata-rata, keberminatan, serta kreativitas. Tentu kadar keberbakatan setiap manusia juga sangat beragam. Karena pada dasarnya setiap manusia yang dilahirkan ke dunia ini pasti memiliki kelebihan dan kekurangan masing-masing.Oleh karena itu, perkembangan bakat sangat dipengaruhi oleh berbagai faktor lingkungan. Menurut Coyle (2009, p.36) secara khusus proses perkembangan bakat diawali dengan adanya pengambilan keputusan yang dilatar belakangi oleh berbagai faktor yang diterima oleh indera manusia yang kemudian dengan serangkain proses hingga membentuk dan menghasilkan gerak yang kompleks dan simultan. Bakat dalam sepakbola memiliki parameter yang beragam. Menurut Gorman (Brown, 2001, p.200) keberbakatan dalam sepakbola merujuk pada karakteristik sebagai berikut: (1) teknik (passing, dribbling, receiving, shooting), (2) taktik (aplikasi skill dalam situasi pertandingan), (3) fisik (kecepatan, kekuatan, daya tahan, koordinasi, keseimbangan), (4) mental (emotional control), (5) gaya hidup (etos kerja, asupan gizi, istirahat, manajemen waktu).

Sepakbola merupakan salah satu jenis permainan yang terpopuler di dunia.Hampir seluruh negara secara masif mengapresiasi permainan sepakbola tidak hanya sekadar sebuah aktivitas olahraga permainan, namun lebih jauh sepakbola memberikan sebuah atmosfer yang sangat berbeda kapan dan dimanapun olahraga tersebut dilakukan, baik dalam situasi pertandingan resmi hingga hanya sekadar aktifitas olahraga rekreasi.Sepakbola sangat berkembang pesat di benua Eropa hingga benua Amerika. Secara khusus, masyarakat Amerika Serikat menggunakan istilah soccer, sedangkan istilah football sendiri mengacu pada sebuah olahraga american football (Hantula, 2012, p.5). Istilah soccer pada awalnya dipopulerkan di negara Inggris, namun seiring berjalannya waktu, istilah football lebih cenderung digunakan di hampir seluruh penjuru dunia.

Sepakbola merupakan salah satu cabang olahraga permainan yang terdiri dari 11 pemain dalam satu regu.Setiap pemain dalam satu regu mempunyai tugas dan fungsi masing-masing. Secara khsusus, posisi setiap pemain jelas sangat membedakan tanggung jawab di lapangan, yang pada akhirnya juga akan membedakan daya jelajah selama pertandingan berlangsung Reilly \& Thomas (Carling, Williams, \& Reilly, 200, p.6). Dimana lebih dari 90\% performa setiap

PJKR_

http://jurnal.unimed.ac.id/2012/index.php/jpehr/index 
pemain tersebut dipengaruhi oleh metabolisme aerobik selama pertandingan sepakbola berlangsung.Permainan sepakbola juga merupakan suatu aktivitas yang terdiri dari hampir 1000 jenis gerak yang dilakukan selama 90 menit.Sepakbola merupakan permainan yang dilakukan pada lapangan yang memiliki area yang terbilang cukup luas dimana bola selalu dalam keadaan bergerak dengan arah yang selalu berubah-ubah (random). Dalam jangka waktu 90 menit ( 2 x 45 menit), seorang pemain sepakbola rata-rata berlari dengan jarak 10 mil atau 9 menit per mil, rata-rata 65-70 menit bola bergulir, dan 1,5-2 gol tercipta per pertandingan resmi (Kirkendall, 201, pp.1-3). Dalam kurun waktu 3-5 detik seorang pemain sepakbola akan melakukan berbagai aktivitas gerak kompleks, diantaranya berlari, berbalik arah, melompat, melakukan tackle, dan lain sebagainya. Dalam sebuah pertandingan sepakbola terdapat berbagai jenis gerak seorang pemain yang bersinggungan dengan pemain lain, antara lain: mendorong dengan sengaja, memotong dari sudut ke sudut, berputar/berbalik arah, serta memulai dan berhenti secara mendadak. Dalam kondisi tersebut seorang pemain harus mampu menjaga keseimbangan dengan stabil untuk berlari dengan kecepatan tinggi, merubah arah dengan reaksi cepat, dan menendang bola dengan kekuatan yang maksimal.Reilly (2007, p.2) juga menambahkan, bahwa secara khusus dalam sebuah pertandingan (demands of the game) sangat dibutuhkan tingkat kebugaran seorang pemain (fitness of players) yang ditentukan oleh proses pemilihan (selection), baik berdasarkan pengeliminasian (omit) maupun kebutuhan taktik (alter tactical role) dan proses latihan (training), baik berdasarkan pengkondisian khusus (specific conditioning) maupun latihan khsusus berdasarkan posisi pemain sepakbola (soccer spesific training-position). Karena pada dasarnya seorang pemain sepakbola dituntut harus selalu mampu menjaga performa positif secara keseluruhan, yakni tingkat kebugaran, motivasi, kondisi lingkungan, dan kompetisi pertandingan.

Menurut Winkler (Stratton, et. al, p.158) bakat dalam sepakbola terdiri dari dari: psikomotor (ketrampilan dan kebugaran), kognitif, dan penyesuaian lingkungan (sosial). Menurut Bompa (SukaJambianto, 2011, p.57) komponen dasar dari biomotor, meliputi: kekuatan, daya tahan, kecepatan, koordinasi, dan fleksibilitas. Adapun komponen-komponen yang lain merupakan perpaduan dari beberapa komponen sehingga membentuk satu peristilahan tersendiri, diantaranya daya ledak yakni gabungan dari kekuatan dan kecepatan, serta kelincahan yakni gabungan dari kecepatan dan koordinasi. Jika berbicara mengenai berbagai komponen biomotor, tentu tingkat kebugaran jasmani memegang peranan yang juga penting dalam pengeksekusian gerak (motor) tersebut. Semakin tinggi tingkat kebugaran jasmani seseorang, maka kemungkinan besar akan semakin baik pula kemampuan biomotornya. Menurut Fox (Suharjana, 2013, p.6) kebugaran jasmani terdiri dari 3 (tiga) jenis, yakni: (1) physical fitness, terdiri dari muscular strength (kekuatan otot), muscular endurance (daya tahan otot), joint flexibility (kelentukan sendi), dan cardiorespiratory fitness (kebugaran jantung-paru), (2) nutritional fitness, terdiri dari body composition (komposisi tubuh), dan control of body weight ((kontrol berat tubuh), dan (3) mental, emotinal dan motor fitness, terdiri dari: mental-emotional stress (ketahanan mental-emosi), endurance (daya

PJKR_

http://jurnal.unimed.ac.id/2012/index.php/jpehr/index 
tahan), strength (kekuatan), agility (kelincahan), flexibility (kelentukan), balance (keseimbangan), dan coordination (koordinasi). Menurut Reilly (2007, pp.20-21) secara khusus, di dalam sebuah pertandingan sepakbola terdapat persentasi aktivitas gerak dasar, antara lain: 36\% gerakan berlari pelan (jog), 24\% gerakan berjalan (walking), 20\% gerakan meluncur (cruise), 11\% gerakan berlari cepat (sprint), 7\% gerakan berbalik arah (move back), dan 2\% gerakan dengan bola (with ball).Selain itu terdapat beberapa bagian tubuh yang juga memainkan peranan penting ketika proses terjadinya gerak selama pertandingan sepakbola, yakni: mata, bahu, otot dada, dinding perut, otot paha, pinggul, pergelangan kaki, otot leher, pinggang, serabut tendon lutut, betis, dan tendon tumit (Bridle, 2011, pp.60-61).

Proses penelusuran bakat dalam sepakbola sudah mengalami perkembangan yang cukup pesat Hasil penemuan terbaru yang sejauh ini masih terus dikembangkan yakni, proses penelusuran bakat dengan metode tes DNA. Tes tersebut sudah dilakukan oleh salah satu klub profesional peserta Liga Inggris (Premiere League) dengan asumsi bahwa anak yang memiliki kualitas DNA yang baik cenderung akan memiliki peluang yang lebih besar untuk berkembang dimulai dari kemampuan aerobik hingga minim resiko cidera. Namun, sejauh ini hasil penelitian masih menyimpan kontroversi. Tes tersebut dianggap tidak manusiawi, karena membatasi keinginan calon atlet yang memiliki minat tinggi untuk menjadi seorang pesepakbola profesional dengan cara yang sulit diterima akal anak usia dini. Perkembangan proses penelusuran bakat di Indonesia masih terbilang belum maksimal, mengingat proses pembinaan yang belum serentak dan tidak seragam. Hal tersebut tentu disebabkan oleh banyak faktor. Namun, secara khusus proses penelusuran bakat dalam sepakbola belum ditangani dengan serius. Karena hingga saat ini belum ada konsep tes yang khusus digunakan secara massal untuk menelusuri bakat dalam sepakbola. Oleh karena itu, perlu dilakukan proses penyusunan tes yang secara khusus digunakan untuk menelusuri keberbakatan dalam sepakbola.Secara khusus, tes memiliki beberapa tujuan penting, antara lain: (1) mengetahui tingkat kemampuan peserta didik, (2) mengukur pertumbuhan dan perkembangan peserta didik, (3) mendiagnosis kesulitan belajar peserta didik, (4) mengetahui hasil belajar dan pengajaran, (5) memotivasi pendidik dan peserta didik dalam proses pembelajaran. Tidak jarang tes digunakan untuk beberapa tujuan, namun tidak akan memiliki keefektifan yang sama untuk semua tujuan. Menurut Cronbach (Azwar, 2013, p.5) tes memiliki 2 (dua) klasifikasi, antara lain: tes yang mengukur performansi maksimal (maximum performance), serta tes yang mengukur performansi tipikal (typical performance).Sebelum merancang sebuah tes, terlebih dahulu harus mempertimbangkan beberapa hal, yakni: acuan kriteria norma dan pengukuran yang akan dipergunakan, serta berbagai kriteria instrumen tes yang baik. Hasil sebuah tes yang baik dapat digunakan untuk beberapa keperluan, yakni: memprediksi kemampuan yang akan datang, menjabarkan kekurang yang dimiliki, mengukur perbaikan yang akan dilakukan, membantu pelatih memprediksi kesuksesan atlet yang akan datang, menempatkan atlet pada latihan yang tepat, dan memotivasi mental atlet (Mackenzie, 2005). Menurut Arikunto (Widoyoko, 2012, p.97) bahwa suatu tes dapat dikatakan memiliki

PJKR_

http://jurnal.unimed.ac.id/2012/index.php/jpehr/index 
karakteristik yang baik apabila memiliki 5 (lima) persyaratan sebagai berikut: (1) validitas, (2) reliabilitas, (3) objektivitas, (4) praktibilitas, dan (5) ekonomis.

\section{Metode}

Model Pengembangan, Penelitian ini merupakan penelitian pengembangan (research and development). Dalam hal ini proses pengembangan dilaksanakan untuk mendapatkan sebuah model tes keterampilan dasar untuk penelusuran bakat calon atlet sepakbola KU 9-10 tahun. Pengembangan ini dilakukan berdasarkan pada hasil observasi lapangan yang secara khusus mengidentifikasi masalah bahwa belum tersedianya model tes bakat yang secara khusus fokus pada faktor keterampilan dasar dalam sepakbola. Pada proses penyusunan instrumen tes juga memperhatikan karaktersitik anak usia 9-10 tahun, dimana pada usia tersebut merupakan kelompok usia paling dasar yang terdapat pada sebagian besar pusat pembinaan usia dini di Provinsi Jambi.

Prosedur Pengembangan, Prosedur pengembangan dalam penelitian ini mengadaptasi langkah-langkah penelitian dan pengembangan Borg \& Gall. Menurut Borg \& Gall (2007, p.589) dalam melaksanakan proses penelitiaan dan pengembangan terdapat 10 (sepuluh) langkah yang harus ditempuh, sebagai berikut: (1) studi pendahuluan dan pengumpulan data (kajian kepustakaan, pengamatan lapangan, membuat kerangka kerja penelitian), (2) perencanaan (merumuskan tujuan penelitian, memperkirakan dana dan waktu yang diperlukan, prosedur kerja penelitian, serta berbagai bentuk partisipasi kegiatan selama kegiatan penelitian), (3) mengembangkan produk awal (perancangan draf awal produk), (4) uji coba awal (mencobakan draf produk ke wilayah dan subjek yang terbatas), (5) revisi untuk menyusun produk utama (revisi produk berdasarkan hasil ujicoba awal), (6) uji coba lapangan utama (uji coba terhadap produk hasil revisi ke wilayah dan subjek yang lebih luas), (7) revisi untuk menyusun produk operasional, (8) uji coba produk operasional (uji efektivitas produk), (9) revisi produk akhir dan (10) diseminasi dan implementasi produk hasil pengembangan. Namun, pada penelitian dan pengembangan disederhanakan menjadi 6 (enam) langkah, sebagai berikut: (1) studi pendahuluan dan pengumpulan data, (2) perencanaan proses penelitian dan pengembangan, (3) validasi produk, (4) uji coba produk, (5) revisi produk, dan (6) implementasi produk.

Desain Uji Coba, Uji coba dilakukan dengan tujuan untuk menyempurnakan model tes dengan mempraktekkannya secara langsung di lapangan.Dalam penelitian dan pengembangan ini, uji coba produk dilakukan dalam 2 (dua) tahapan, yaitu uji coba skala kecil dan uji coba skala besar.Uji coba skala kecil dilakukan terhadap 30 testi.Sementara uji coba skala besar dilakukan pada 416 testi. Kemudian dalam tahapan uji coba di lapangan peran para ahli (judgement expert), pelatih sepakbola usia dini, serta guru penjaskes sekolah dasar adalah untuk mengobservasi kelayakan produk berdasarkan fakta yang diperoleh hingga menghasilkan sebuah model tes yang valid dan reliabel.

Jenis Data, Data yang dikumpulkan dari penelitian dan pengembangan ini berupa data kualitatif dan data kuantitatif. Data kualitatif diperoleh dari: (1) hasil diskusi dengan para pelatih sepakbola usia dini dan guru penjaskes sekoalh dasar, dan (2) saran dan masukan para ahli terhadap produk. Sementara data kuantitatif diperoleh dari: (1) penilaian para ahli, pelatih sepakbola usia dini, dan guru penjaskes sekolah dasar terhadap hasil uji coba skala kecil, dan (2) hasil analisis 
data untuk menentukan tingkat validitas, reliabilitas, serta skala penilaian (norma) instrumen tes pada uji coba skala besar

Instrumen Pengumpulan Data, Model Tes, model tes yang digunakan oleh para testi adalah instrumen yang diguanakan untuk mengumpulkan data pengukuran di lapangan. Adapun model tes yang digunakan terdiri dari 4 (empat) butir tes, yaitu: basic ball juggling test digunakan untuk mengukur keterampilan dasar mengontrol bola, shuttle ball passing test digunakan untuk mengukur keterampilan dasar menendang bola, zigzag ball dribbling test digunakan untuk mengukur keterampilan dasar menggiring bola, serta agility run test digunakan untuk mengukur keterampilan berlari tanpa bola.

Analisis Data, analisis data merupakan proses mencari dan menyusun secara sistematis data yang diperoleh dari hasil wawancara, catatan lapangan, dan data-data lain, sehingga dapat mudah dipahami, dan temuan tersebut dapat diinformasikan kepada pihak lain. Analisis data dilakukan dengan mengorganisasikan data, menjabarkan ke dalam unit-unit, melakukan sintesa, menyusun ke dalam pola, memilih mana yang penting dan yang akan dipelajari, serta membuat kesimpulan yang dapat disampaikan kepada orang lain (Sugiyono, 2012, p.244). Teknik analisis data yang digunakan dalam penelitian dan pengembangan ini.

\section{Uji Validitas}

Uji validitas dilakukan untuk mengetahui tingkat kesahihan data yang ada.Adapun uji validitas yang digunakan pada penelitian dan pengembangan ini yakni, uji validitas isi.Uji validitas isi dilakukan untuk mengestimasi instrumen tes yang dilaksanakan oleh para ahli (expert judgement). Analisis data dilakukan dengan menggunakan inter-items correlations, yakni mengkorelasikan data hasil skor setiap butir tes dengan skor total, menggunakan teknik analisis korelasi product moment dari Pearson. Perhitungan tersebut dilakukan untuk mengetahui koefisien validitas masing-masing butir tes yang disusun.Data yang diperoleh dari setiap butir tes diuji validitasnya dengan menggunakan bantuan program komputer SPSS 22.0 Version IBM.

\section{Uji Reliabilitas}

Uji reliabilitas dilakukan untuk menggambarkan konsistensi hasil pengukuran pada uji coba skala besar.Dalam hal ini, pelaksanaan setiap butir tes dilakukan sebanyak 2 (dua) kali. Uji reliabilitas dilakukan dengan menggunakan test-retest Cronbach's Alpha dengan bantuan program komputer SPSS 22.0 Version IBM.

\section{Z Score}

Z Scoredilakukan untuk menyamakan satuan dari skor setiap butir tes, sehingga hasil dari setiap butir dapat dijumlahkan, hasil dari penjumlahan ini berupa total skor. Hal ini dilakukan karena skor perolehan setiap butir tes yang terdiri dari berbagai jenis, yakni dalam bentuk frekuensi satuan jumlah dan 
perolehan satuan waktu. Proses Z Score dilakukan dengan bantuan program komputer SPSS 22.00 Version IBM.

\section{Grading (Penilaian)}

Penilaian dilakukan untuk menerjemahkan skor hasil tes yang telah dikonversikan ke dalam klasifikasi evaluatif menurut karakteristik yang relevan, dengan menggunakan penilaian yang mengacu pada suatu norma (normreferenced evaluation). Grading dipergunakan untuk menentukan skala penilaian (norma) tes. Adapun penilaian yang dipergunakan merupakan penilaian dengan skor standar, yakni dengan mengubah skor hasil tes ke dalam bentuk penyimpangannya dari mean dalam satuan deviasi standar.

\section{Uji Deskriptif}

Uji deskriptif dilakukan untuk menganalisis data dengan cara mendeskripsikan serta menggambarkan data yang telah terkumpul sebagaimana adanya yang bertujuan untuk membuat kesimpulan yang berlaku untuk umum (generalisasi). Statistik deskriptif hanya digunakan untuk mendeskripsikan data hasil penelitian sehingga data tersebut dapat dengan mudah untuk dipahami dan dimengerti secara umum.

\section{Pembahasan}

Hasil Penelitian, Hasil penilaian para ahli, pelatih sepakbola, dan guru penjaskes terhadap model tes keterampilan dasar untuk penelusuran bakat calon atlet sepakbola KU 9-10 tahun meliputi observasi terhadap model tes yang dikembangkan.

\begin{tabular}{ccc}
\multicolumn{3}{c}{ Tabel 1. Hasil Penilaian Kualitas Model Tes } \\
\hline AHLI MATERI & \multicolumn{1}{c}{ ASPEK PENILAIAN } & SKOR \\
Ahli & 12345678910 & 1111111 \\
$\begin{array}{c}\text { Sepakbola } \\
\text { Ahli Tes } \\
\text { Olahraga } \\
\text { Pelatih }\end{array}$ & 1111111111 & 10 \\
$\begin{array}{c}\text { Sepakbola I } \\
\text { Pelatih }\end{array}$ & 1111111111 & 10 \\
$\begin{array}{c}\text { Sepakbola } \\
\text { II }\end{array}$ & 1111111111 & 10 \\
Guru & 1111111111 & 10
\end{tabular}

Nilai Maksimal $=50$

Penjaskes

A : Nilai yang diperoleh

B : Nilai Maksimal

A / B X $100 \%$

$50 / 50 \times 100=100 \%=$ Kategori sangat baik

Adapun data yang diperoleh dari hasil pengukuran dengan menggunakan basic ball juggling test, yaitu: 


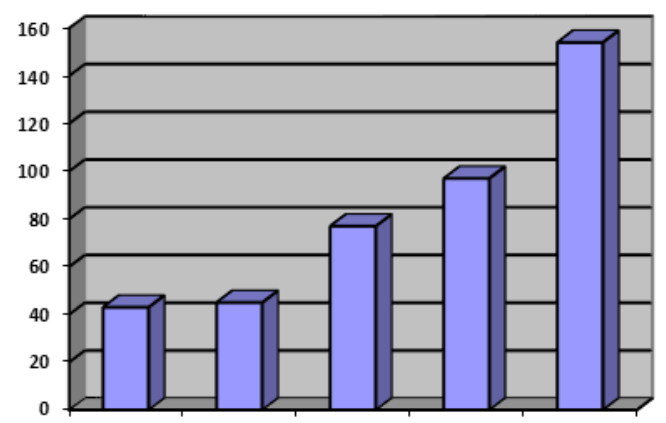

Gambar 1. Histogram Basic Ball Juggling Test

Adapun keterangan data dari hasil Basic Ball Juggling Test yakni: (a) kategori baik sekali ( $\geq 27$ ) sebanyak 43 testi, (b) kategori baik (21-21) sebanyak 45 testi, (c) kategori sedang (15-20) sebanyak 77 testi, (d) kategori buruk (9-14) sebanyak 97 testi, dan (e) kategori sangat buruk $(\leq 8)$ sebanyak 154 testi.

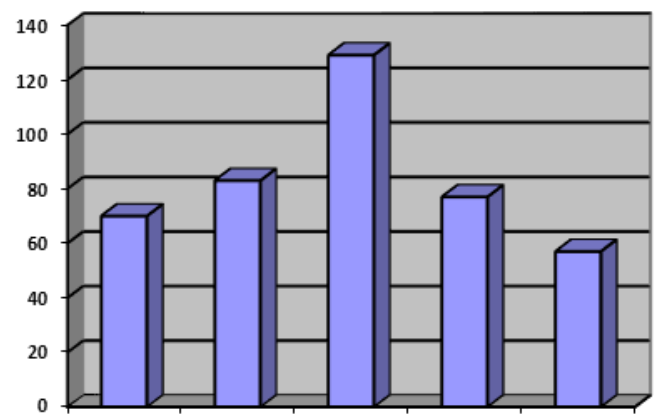

Gambar 2.Histogram Shuttle Ball Passing Test

Adapun keterangan data dari hasil Shuttle Ball Passing Test yakni: (a) kategori baik sekali ( $\geq 9$ ) sebanyak 70 testi, (b) kategori baik (7-8) sebanyak 83 testi, (c) kategori sedang (5-6) sebanyak 129 testi, (d) kategori buruk (3-4) sebanyak 77 testi, dan (e) kategori sangat buruk $(\leq 2)$ sebanyak 57 testi.

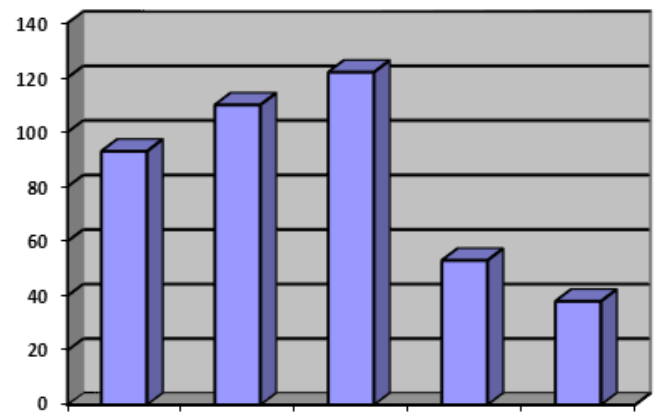

Gambar 3. Histogram Zigzag Ball Dribbling Test 
Adapun keterangan data dari hasil Zigzag Ball Dribbling Test yakni: (a) kategori baik sekali $(\leq 13,68)$ sebanyak 93 testi, (b) kategori baik $(13,69-15,67)$ sebanyak 110 testi, (c) kategori sedang (15,68-17,67) sebanyak 122 testi, (d) kategori buruk $(17,68-19,66)$ sebanyak 53 testi, dan (e) kategori sangat buruk $(\geq 19,67)$ sebanyak 38 testi.

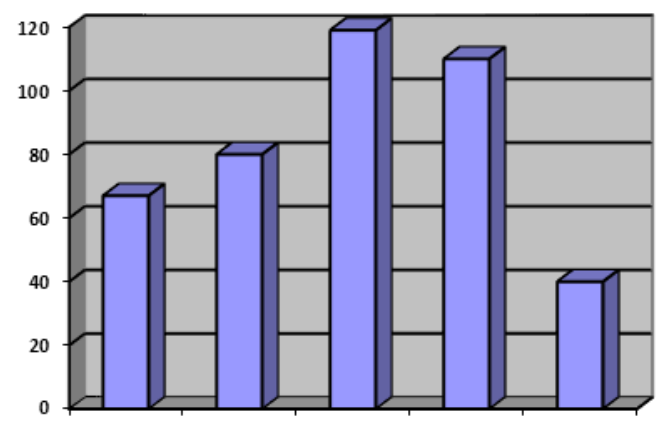

Gambar 4. Histogram Agility Run Test

Adapun keterangan data dari hasil Agility Run Test yakni: (a) kategori baik sekali $(\leq 13,25)$ sebanyak 67 testi, (b) kategori baik $(13,26-14,62)$ sebanyak 80 testi, (c) kategori sedang (14,63-16,00) sebanyak 119 testi, (d) kategori buruk (16,01-17,37) sebanyak 110 testi, dan (e) kategori sangat buruk $(\geq 17,38)$ sebanyak 40 testi.

Sebuah proses penelitian dan pengembangan dapat dilakukan apabila terdapat data hasil analisis kebutuhan berdasarkan fakta empiris yang ditemukan di lapangan. Penelitian dan pengembangan model tes keterampilan dasar untuk penelusuran bakat calon atlet sepakbola KU 9-10 tahun menggunakan model deskriptif prosedural, dimana tes menggariskan langkah pelaksanaan penelitian dan pengembangan yang harus dilaksanakan secara bertahap dan berurutan untuk menghasilkan sebuah produk yang siap pakai. Tahapan paling dasar yang harus dilakukan untuk merancang sebuah model tes yakni, konseptualisasi permasalahan. Selanjutnya apabila konseptualisme permasalahan telah dilaksanakan, maka pengembangan rancangan produk dapat segera dilakukan, dengan proses Focus Group Discussion (FGD). Selanjutnya apabila penyusunan rancangan produk telak dilakukan, maka tahap uji coba dilakukan dalam beberapa tahapan. Langkah tersebut digunakan untuk mengembangkan sebuah model dengan harapan akan memperoleh instrumen tes yang valid dan reliabel, yakni dengan melibatkan peran para ahli (expert judgement) dalam bidang sepakbola dan tes pengukuran olahraga.

Instrumen tes keterampilan dasar untuk penelusuran bakat calon atlet sepakbola KU 9-10 tahun mengacu pada proses Focus Group Discussion (FGD) yang dilakukan bersama dengan para pelatih pusat pembinaan sepakbola usia dini (SSB) dan guru penjaskes SD. Selanjutnya hasil diskusi tersebut di validasi oleh para ahli untuk diolah menjadi sebuah desain produk awal (draft) yang siap untuk diuji cobakan pada uji coba skala kecil. Adapun model tes keterampilan dasar untuk penelusuran bakat calon atlet sepakbola KU 9-10 tahun mengacu pada tes

PJKR_

http://jurnal.unimed.ac.id/2012/index.php/jpehr/index 
yang sudah ada, namun belum memiliki skala penilaian (norma) yang sesuai dengan sasaran produk akhir.

Setelah dilakukan uji coba produk pada skala kecil, dilakukan revisi produk untuk memperbaiki segala bentuk kekurangan dan kelemahan yang diperoleh dari hasil uji coba skala kecil berupa analisis hasil video rekaman pelaksanaan tes secara keseluruhan.Setelah direvisi, maka produk siap digunakan pada tahap uji coba selanjutnya, yakni pada uji coba skala besar. Adapun tujuan dilakukannya uji coba skala besar, yakni untuk menentukan tingkat validitas dan reliabilitas tes serta menyusun skala penilaian (norma) tes. Selanjutnya setelah tes dinyatakan valid dan reliabel serta telah memiliki skala penilaian, maka dilakukan proses penyusunan produk akhir yang dikemas dalam buku panduan (modul) serta video tutorial pelaksanaan tes (CD). Setelah produk akhir selesai disusun, maka selanjutnya dilakukan proses implementasi produk pada pusat pembinaan sepakbola usiadini di kawasan Provinsi Daerah Istimewa Jambi.

\section{Simpulan}

Model tes keterampilan dasar untuk penelusuran bakat calon atlet sepakbola KU 9-10 tahun dinyatakan layak digunakan dengan rincian sebagai beikut: butir basic ball juggling test dengan koefisien validitas 0.878 dan koefisien reliabilitas 0.896 , butir shuttle ball passing test dengan koefisiean validitas 0.861 dan koefisien reliabilitas 0.927 , butir zigzag ball dribbling test dengan koefisiean validitas 0.843 dan koefisien reliabilitas 0.940 , butir agility run test dengan koefisiean validitas 0.747 dan koefisien reliabilitas 0.976 .

Adapun klasifikasi penilaian pada model te kerampilan dasar untuk penelusuran bakat sebagai berikut: jumlah (total) nilai $\geq 17$ dinyatakan sangat berbakat, jumlah (total) nilai 14-16 dinyatakan berbakat, jumlah (total) nilai 11-13 dinyatakan cukup berbakat, jumlah (total) nilai 8-10 dinyatakan tidak berbakat, dan jumlah (total) nilai $\leq 7$ dinyatakan sangat tidak berbakat.

PJKR_

http://jurnal.unimed.ac.id/2012/index.php/jpehr/index 


\section{Rujukan}

Azwar, Saifuddin, 2013. Reliabilitas dan validitas. Jambi: Pustaka Pelajar Offset.

Beswick, Bill, 2010. Focused for soccer (second edition). United States of America: Human Kinetics.

Bridle, Bob, 2011. Essentials soccer skills: key tips and techniques to improve your game. United Satates of America: DK Publishing.

Brown, Jim, 2001. Sports talent: how to identify and develop outstanding athletes. United States of America: Human Kinetics.

Carling, C., Williams, A. M., \& Reilly, T, 2005. Handbook of soccer match analysis: a systematic approach to improving performance. London: Taylor and Francis Group.

Coyle, Daniel, 2009. The talent code: greatness isn't born, it's grown, here's how. New York: Bantam Dell.

Gall, M.D., Gall, J.P., \& Borg,W.R, 2007. Educational research: an introduction (eighth edition). New York: Pearson Education, Inc.

Hantula, Richard, 2012. Science at work in soccer. New York: Marshall Cavendish Benchmark.

Kirkendall, D.T, 2011. Soccer anatomy. United States of America: Human Kinetics.

Mackenzie, Brian, 2005. 101 perfomance evaluation tests. London: Electric Word plc.

Mardapi, Djemari, 2008. Teknik penyusunan instrumen tes dan non-tes.Jambi: Mitra Cendikia Press.

Martinek, Tom, \& Hellison, Don, 2009. Youth leadership in sport and phsycal education. United States of America: Palgrave Macmillan.

Reilly, Thomas, 2007. The science of trainning soccer: a scientific approach to developing strength, speed, and endurance. London: Taylor and Francis Group.

Sternberg, R.J., \& Davidson, J.E, 2005. Conceptions of giftedness: second edition (Eds.). New York: Cambridge University Press.

Stratton, et. Al, 2004. Youth soccer: from science to performance. New York: Taylor and Francis Group.

Sugiyono, 2012. Metode penelitian kuantitatif, kualitatif, dan $r \& d$. Bandung: Alfabeta.

Suharjana, 2013. Kebugaran Jasmani.Jambi: Jogja Global Media.

Sukadianto, \& Muluk, Dangsina, 2011. Pengantar teori dan metodologi melatih fisik. Bandung: Lubuk Agung.

Widoyoko, S.E.P, 2012. Teknik penyusunan instrumen penelitian. Jambi: Pustaka Belajar. 